\title{
Root exudation and root development of lettuce (Lactuca sativa L. CV. Tizian) as affected by different soils
}

\author{
G. Neumann ${ }^{1 *}$, S. Bott ${ }^{1}$, M. A. Ohler ${ }^{1}$, H.-P. Mock ${ }^{2}$, R. Lippmann ${ }^{2}$, R. Grosch ${ }^{3}$ and K. Smalla ${ }^{4}$ \\ ${ }^{1}$ Department of Nutritional Crop Physiology, Institute of Crop Science (340h), University of Hohenheim, Stuttgart, Germany \\ ${ }^{2}$ Leibniz-Institut für Pflanzengenetik und Kulturpflanzenforschung, Gatersleben, Germany \\ ${ }^{3}$ Department Plant Health, Leibniz Institute of Vegetable and Ornamental Crops Großbeeren/Erfurt e.V., Großbeeren, Germany \\ ${ }^{4}$ Julius Kühn-Institut Federal Research Centre for Cultivated Plants, Institute for Epidemiology and Pathogen Diagnostics, Braunschweig, Germany
}

\section{Edited by:}

Gabriele Berg, Graz University of Technology, Austria

Reviewed by:

Kemal Kazan, Commonwealth Scientific and Industrial Research Organization, Australia

Nai-Chun Lin, National Taiwan

University, Taiwan

*Correspondence:

G. Neumann, Department of Nutritional Crop Physiology, Institute of Crop Science (340h), University of Hohenheim, 70593 Stuttgart,

Germany

e-mail:gd.neumann@t-online.de
Development and activity of plant roots exhibit high adaptive variability. Although it is well-documented, that physicochemical soil properties can strongly influence root morphology and root exudation, particularly under field conditions, a comparative assessment is complicated by the impact of additional factors, such as climate and cropping history. To overcome these limitations, in this study, field soils originating from an unique experimental plot system with three different soil types, which were stored at the same field site for 10 years and exposed to the same agricultural management practice, were used for an investigation on effects of soil type on root development and root exudation. Lettuce (Lactuca sativa L. Cv. Tizian) was grown as a model plant under controlled environmental conditions in a minirhizotrone system equipped with root observation windows (rhizoboxes). Root exudates were collected by placing sorption filters onto the root surface followed by subsequent extraction and GC-MS profiling of the trapped compounds. Surprisingly, even in absence of external stress factors with known impact on root exudation, such as $\mathrm{pH}$ extremes, water and nutrient limitations/toxicities or soil structure effects (use of sieved soils), root growth characteristics (root length, fine root development) as well as profiles of root exudates were strongly influenced by the soil type used for plant cultivation. The results coincided well with differences in rhizosphere bacterial communities, detected in field-grown lettuce plants cultivated on the same soils (Schreiter et al., this issue). The findings suggest that the observed differences may be the result of plant interactions with the soil-specific microbiomes.

\section{Keywords: lettuce, root exudates, root morphology, soil effects}

\section{INTRODUCTION}

Root exudates of higher plants with nutritional, signaling, and antibiotic functions are shaping rhizosphere-microbial communities, which in turn can exert stimulatory or inhibitory effects on plant growth and development. Already Hiltner (1904) postulated that specific patterns of root exudation in different plant species may recruit a specific rhizosphere microflora, which may comprise beneficial partners but also pathogens as uninvited guests. $\mathrm{He}$ also pointed out that a more detailed knowledge of these interactions may open perspectives for practical applications in agriculture and plant protection. Nowadays, the availability of novel techniques for the characterization of microbial communities by high throughput sequencing approaches, metabolomics and the development of non-destructive, localized exudate sampling techniques (Neumann et al., 2009; Bakker et al., 2012; Chaparro et al., 2013) opens the way for a more detailed and comprehensive look on the interactions between rhizosphere microbiomes and roots of their host plants. During the last two decades enormous progress was achieved in the characterization of factors determining root exudation, which exhibits high variability within different plant species and even cultivars, within different root zones and developmental stages of individual plants and in response to various biotic and abiotic stress factors (Neumann, 2007; Neumann and Römheld, 2007; Badri and Vivanco, 2009). An increasing number of investigations meanwhile also address the interactions between root exudates and corresponding changes of the microflora in the rhizosphere (Marschner et al., 2002; Weisskopf et al., 2006; Bakker et al., 2012).

In the present study, we hypothesized that different soil types with different physicochemical properties will influence root growth patterns and root exudation, which in turn may have an impact on composition and function of rhizospheremicrobial communities (see Schreiter et al., this issue). The enormous plasticity of root growth and root exudation in response to different soil conditions and particularly to stress factors, such as nutrient limitation, mineral toxicities, and extremes in soil moisture and soil structure, is a well-described phenomenon (Neumann and Römheld, 2002, 2007; Neumann, 2007). In our study, we used field soils originating from a unique experimental plot system with three different soil types, which were stored at the same field site for 10 years under the same agricultural management and used in parallel by Schreiter et al. (this issue) to characterize the influence of soil type on rhizosphere-bacterial communities under field conditions. This approach offered the opportunity to study the influence of 
soil properties independent from cropping history or climatic factors.

Lettuce plants (cv. Tizian) were grown in minirhizotrons, equipped with root observation windows (Neumann, 2006a), which allowed root growth monitoring and localized collection of root exudates and rhizosphere soil solution from defined root zones by use of sorption filters (Neumann, 2006b; Haase et al., 2007) with subsequent re-extraction and GC-MS profiling of the exudate patterns (Lippmann et al., 2009). Due to the limited available field plot size, unfortunately direct collection of root exudates under field conditions by use of root windows (Neumann et al., 2009) was not possible.

\section{MATERIALS AND METHODS PLANT CULTIVATION}

Lactuca sativa L. cv. Tizian seedlings were pre-cultivated until the 2-leaf stage $(\mathrm{BBCH} 12)$ in peat culture substrate sand mixture (7:3 w/w; TKS1-Anzuchtsubstrat, Floragard, Germany). Thereafter, the seedlings were transferred to minirhizotrons (rhizoboxes) with transparent root observation windows $(36 \times 11.5 \times 2.5 \mathrm{~cm}$; Neumann, 2006a) filled each with $1 \mathrm{~kg}$ of the selected test soils (Figure 1).

The experimental system included three soils of different origin: Arenic-Luvisol with less silty sand and 5.5\% clay [diluvial

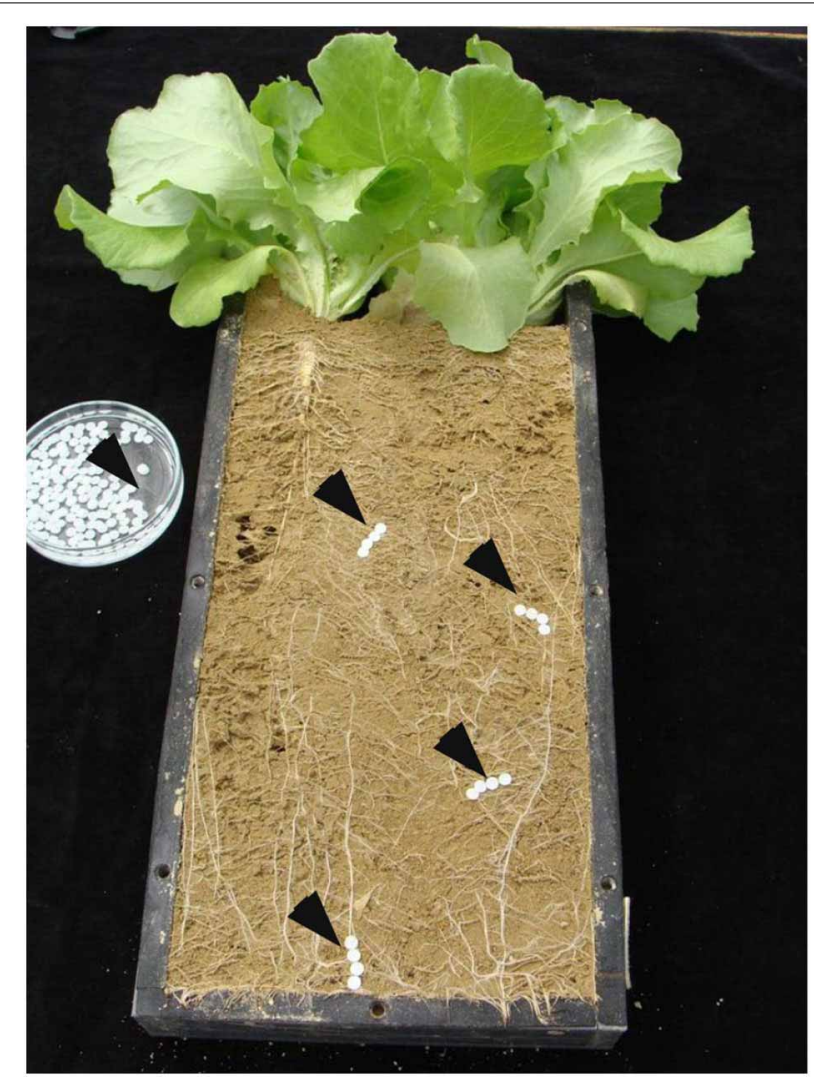

FIGURE 1 | Lettuce plants Lactuca sativa L. cv. Tizian (BBCH 19) grown on loess loam. Root observation window of a minirhizotron (rhizobox) prepared for exudate collection with sorption filters (indicated by black arrows). sand (DS)], Gleyic-Fluvisol with heavy sandy loam and 27.5\% clay [alluvial loam (AL)], and Luvic-Phaeozem with medium content of clayey silt and $17.2 \%$ clay [loess loam (LL)]. Soil properties are summarized in Table $\mathbf{1 .}$

To exclude nutrient limitation, prior to transplanting, the soils received a basal macronutrient fertilization of $\mathrm{N}, \mathrm{P}, \mathrm{K}$, and $\mathrm{Mg}$. Nitrogen was applied as $\mathrm{CaNO}_{3}$ at $100 \mathrm{mg} \mathrm{N} \mathrm{kg}^{-1}$ soil, $\mathrm{P}$ as $\mathrm{Ca}\left(\mathrm{H}_{2} \mathrm{PO}_{4}\right)_{2}$ at $100 \mathrm{mg} \mathrm{P} \mathrm{kg}^{-1}$ soil, $\mathrm{K}$ as $\mathrm{K}_{2} \mathrm{SO}_{4}$ at $150 \mathrm{mg} \mathrm{K} \mathrm{kg}^{-1}$ soil and $\mathrm{Mg}$ as $\mathrm{MgSO}_{4}$ at $50 \mathrm{mg} \mathrm{Mg} \mathrm{kg}{ }^{-1}$ soil. Final soil moisture level was adjusted to $18-20 \% \mathrm{w} / \mathrm{w}$ and controlled gravimetrically during the culture period.

Rhizoboxes were fixed at an angle of $45^{\circ}$ to promote root development along the observation windows and plants were cultivated until $\mathrm{BBCH} 19$ in a growth chamber with a $16 \mathrm{~h}$ light period $\left(200 \mu \mathrm{mol} \mathrm{m}^{-2} \mathrm{~s}^{-1}\right), 60 \%$ rel. humidity and a day/night temperature of $25^{\circ} / 23^{\circ} \mathrm{C}$.

\section{FINAL HARVEST AND EXUDATE SAMPLING}

Prior to final harvest (BBCH 19; 5 weeks after transplanting), the root observation windows were opened and root exudates were collected by placing sorption filters onto the surface of $2 \mathrm{~cm}$ sub-apical root zones (Figure 1) according to the method described by Haase et al. (2007). The time point for exudate sampling was selected since root growth, shoot to root carbohydrate partition and root exudation usually is particularly intense during vegetative growth and declines after entering the generative phase (Marschner, 1995). The collection period was $4 \mathrm{~h}$ and the filters were subsequently stored at $-20^{\circ} \mathrm{C}$ until further analysis. Thereafter, roots were washed out of the soil using sieves with 1 and $0.5 \mathrm{~mm}$ mesh size. Roots were dried on filter paper and fresh biomass was recorded. Thereafter, the root samples were stored in $30 \%(\mathrm{v} / \mathrm{v})$ ethanol until further analysis. Biomass of the shoot material was recorded and dried at $60^{\circ} \mathrm{C}$ for mineral nutrient analysis. Root analysis was performed using the WinRhizo system (Regent Instruments, Quebec, Canada).

\section{MINERAL NUTRIENT ANALYSIS}

For determination of the plant-nutritional status, $500 \mathrm{mg}$ of dried leaf material was ashed in a muffle furnace at $500^{\circ} \mathrm{C}$ for $5 \mathrm{~h}$. After cooling, the samples were extracted twice with $2 \mathrm{~mL}$ of $3.4 \mathrm{M}$ $\mathrm{HNO}_{3}$ until dryness to precipitate $\mathrm{SiO}_{2}$. The ash was dissolved in $2 \mathrm{~mL}$ of $4 \mathrm{M} \mathrm{HCl}$, subsequently diluted ten times with hot deionized water, and boiled for $2 \mathrm{~min}$. After addition of $0.1 \mathrm{~mL} \mathrm{Cs} / \mathrm{La}$ buffer to $4.9 \mathrm{~mL}$ ash solution, $\mathrm{Fe}, \mathrm{Mn}$, and $\mathrm{Zn}$ concentrations

Table 1 | Characteristics of the field soils used for the experiments.

\begin{tabular}{lcccccc}
\hline Soil type & $\mathbf{p H}$ & $\begin{array}{c}\mathbf{C t} \\
{[\%]}\end{array}$ & $\begin{array}{c}\text { TRD } \\
{\left[\mathbf{g} / \mathbf{c m}^{\mathbf{3}} \text { ] }\right.}\end{array}$ & $\begin{array}{r}\text { FAT } \\
\text { [\%] }\end{array}$ & $\begin{array}{c}\text { P CAL. } \\
{[\mathbf{m g} / \mathbf{1 0 0} \mathbf{~ g ]}}\end{array}$ & $\begin{array}{c}\text { K CAL. } \\
{[\mathbf{m g} / \mathbf{1 0 0} \mathbf{~ g ]}}\end{array}$ \\
\hline Loess loam & 7.3 & 1.90 & 1.36 & 23.6 & 26.1 & 30.0 \\
Diluvial sand & 6.1 & 0.80 & 1.46 & 7.7 & 25.4 & 12.3 \\
Alluvial loam & 6.7 & 1.80 & 1.31 & 34.9 & 46.0 & 26.0 \\
\hline
\end{tabular}

Ct, total carbon content; TRD, bulk density; FAT, fine grained particles/ particles $<6.3 \mu \mathrm{m}$. 
were measured by atomic absorption spectrometry (UNICAM 939, Offenbach/Main, Germany).

\section{EXUDATE PROFILING}

The extraction of the sorption filters containing root exudates and rhizosphere soil solution was conducted with $80 \%$ methanol. Filters were removed by centrifugation, and the supernatant was evaporated to dryness at $30^{\circ} \mathrm{C}$ using a speed vac concentrator (Savant, Farmington, USA) and stored at $-80^{\circ} \mathrm{C}$ until further analysis. For analysis, supernatants were re-dissolved in $200 \mu \mathrm{L}$ methanol, transferred into GC-MS glass vials and evaporated to dryness at $30^{\circ} \mathrm{C}$. Derivatisation was performed online directly prior to injection using a MPS Autosampler (Gerstel, Mühlheim a. d. R., Germany) by adding $25 \mathrm{uL}$ methoxyhydroxymethylamine (20 $\mathrm{mg} \mathrm{mL}^{-1}$ in pyridine) and incubation for $2 \mathrm{~h}$ at $37^{\circ} \mathrm{C}, 350 \mathrm{rpm}$. Thereafter, $50 \mu \mathrm{L}$ MSTFA including standard alcanes from Sigma C7-C30 $(0.1 \% \mathrm{v} / \mathrm{v})$ were added and incubated for $30 \mathrm{~min}$ at $37^{\circ} \mathrm{C}, 350 \mathrm{rpm}$.

One $\mu \mathrm{L}$ aliquots were analyzed by an Agilent 7890 gas chromatograph (Agilent, Santa Clara, CA, USA) in the splitless mode, coupled to a TOF mass spectrometer GCT Premier (Waters Corporation, Eschborn, Germany). Separation was performed on a Rxi ${ }^{\circledR 5 S i l ~ M S ~ I n t e g r a ~ c o l u m n ~(R e s t e k) ~ w i t h ~} 0.25 \mathrm{~mm}$ inner diameter and $0.25 \mu \mathrm{m}$ film thickness, including a $5 \mathrm{~m}$ guard column according to Lippmann et al. (2009). Injection temperature was $240^{\circ} \mathrm{C}$. The temperature program for GC separation was: $3 \mathrm{~min}$ $80^{\circ} \mathrm{C}$ isothermal followed by a ramp of $5^{\circ} \mathrm{C} \mathrm{min}^{-1}$ to $300^{\circ} \mathrm{C}$ for $5 \mathrm{~min}$. Mass spectroscopical (MS) data were recorded with Mass Lynx 4.1 (Waters Corporation) at a rate of 10 spectra s$^{-1}$ in a range of $50-700 \mathrm{~m} / \mathrm{z}$. Metabolites were identified automatically with the internal software ChromaLynx using the NIST 5 library and interesting components were verified manually by comparison with reference spectra. For principal component analysis (PCA) MarkerLynx (Waters Corporation) was used with following settings: 20 masses per retention time in the range of $100-330 \mathrm{~m} / \mathrm{z}$ and a tolerance of $0.05 \mathrm{Da}$ were isolated at a threshold at $5 \%$ of base peak intensity. Pareto algorithm was used for visualization.

\section{RESULTS}

\section{ROOT GROWTH CHARACTERISTICS}

Biomass production and particularly root length were significantly influenced by the selected soil types (Table 2). Root growth characteristics of lettuce plants grown on DS and LL were significantly different from AL. Total root length on AL, mainly represented by fine roots (diameter $<0.4 \mathrm{~mm}, 70 \%$ ) was $2.5-4$ fold increased as compared with DS and LL, respectively. This was also reflected in a significantly higher (fine) root length, root biomass and a lower average root diameter of lettuce plants grown on AL. However, differences in root growth were not associated with corresponding differences in shoot biomass production and surprisingly, the highest shoot biomass was detected in lettuce plants grown on LL with development of the smallest root system.

\section{ROOT EXUDATES}

At $\mathrm{BBCH} 19$ (5 weeks after transplanting), root development along the root observation window was sufficiently expressed to enable the collection of root exudates and rhizosphere soil solution from defined sub-apical root zones in young actively growing roots (Figure 1), which have been identified in many earlier studies as the sites of the most intense expression of root exudation, nutrient uptake and root-induced rhizosphere-chemical changes (for review see Neumann and Römheld, 2007).

In total 33 compounds were identified by GC-MS profiling in the soil solutions collected with sorption filters from the root surface and rhizosphere of $2 \mathrm{~cm}$ sub-apical root zones, comprising 17 amino acids and amides, 8 sugars, and sugar alcohols, 5 organic acids as well as ornithine, urea, and phosphate (Table 3). Benzoic and lauric acids were detected as exudate compounds with allelopathic and antibiotic properties (Walters et al., 2003; Lee et al., 2006; Yoon et al., 2012).

PCA analysis revealed clear differences in the root exudate profiles collected from lettuce plants grown on the different soils (Figure 2), with DS separated from AL. However, with the exception of several amino acids (beta-alanine, glutamate, 4-amino butyric acid), the differences were rather quantitative than qualitative (Table 3).

Interesting quantitative differences were observed for low molecular weight sugars, such as glucose, fructose, mannose, maltose, sucrose, and trehalose, which were much less abundant in samples collected from plants grown on AL as compared with DS or LL soil (Table 2). This is also reflected in the cumulative quantification of all sugars based on peak areas (Table 4), where the detected amounts increased in the order $\mathrm{AL}<\mathrm{DS}<\mathrm{LL}$. The same trend was detectable for the cumulative quantification of amino acids but not for organic acids (Table 4).

Urea was detected in similar amounts in soil solutions collected from the rhizosphere and from the bulk soil, while phosphate was present exclusively in rhizosphere soil solutions (data not shown).

The plants did not show any macronutrient disorders, since all soils received a standard $\mathrm{N}, \mathrm{P}, \mathrm{K}, \mathrm{Mg}$ fertilization prior to

Table 2 | Biomass production and root characteristics of Lactuca sativa L. cv. Tizian (BBCH19), grown on three different soils.

\begin{tabular}{|c|c|c|c|c|c|}
\hline Soil type & $\begin{array}{c}\text { Shoot fresh weight } \\
{\left[\text { g plant }^{-1}\right]}\end{array}$ & $\begin{array}{l}\text { Root fresh weight } \\
{[\text { [g plant }}\end{array}$ & $\begin{array}{l}\text { Total root length } \\
\text { [cm plant } \\
\text { [c] }\end{array}$ & $\begin{array}{c}\text { Fine root length } \\
\text { [cm plant }{ }^{-1} \text { ] } \\
0-0.4 \mathrm{~mm} \text { diameter }^{-}\end{array}$ & $\begin{array}{l}\text { Average root diameter } \\
{[\mathrm{mm}]}\end{array}$ \\
\hline Loess loam & $9.07 \pm 1.02 a$ & $0.30 \pm 0.04 b$ & $126.8 \pm 14.9 b$ & $87.3 \pm 12.5 b$ & $0.49 \pm 0.02 b$ \\
\hline Diluvial sand & $5.32 \pm 0.60 a$ & $0.24 \pm 0.05 b$ & $197.1 \pm 27.5 b$ & $150.9 \pm 18.2 b$ & $0.43 \pm 0.01 b$ \\
\hline
\end{tabular}

Means $\pm S E$ of four independent replicates. In each column different characters indicate significant differences (One-way ANOVA, Holm-Sidak test, $p=0.05)$. 
Table 3 | List of low molecular-weight compounds detected by GC-MS root exudate profiling from roots of Lactuca sativa cv Tizian (BBCH19) grown on three different soils.

\begin{tabular}{|c|c|c|c|c|}
\hline $\begin{array}{l}\text { Chemical } \\
\text { group }\end{array}$ & Compound & $\begin{array}{l}\text { Loess } \\
\text { loam }\end{array}$ & $\begin{array}{l}\text { Alluvial } \\
\text { loam }\end{array}$ & $\begin{array}{l}\text { Diluvial } \\
\text { sand }\end{array}$ \\
\hline \multirow{17}{*}{$\begin{array}{l}\text { Amino acids } \\
\text { and amines }\end{array}$} & Alanine & + & + & ++ \\
\hline & beta-Alanine & + & - & + \\
\hline & Aspartate & + & + & + \\
\hline & Glutamate & - & - & + \\
\hline & Glutamine & + & + & + \\
\hline & Glycine & +++ & ++ & ++ \\
\hline & Leucine & ++ & + & + \\
\hline & Isoleucine & + & + & + \\
\hline & Proline & + & + & + \\
\hline & 4-Hydroxyproline & + & + & + \\
\hline & Pyroglutamate & ++ & + & + \\
\hline & Serine & ++ & ++ & + \\
\hline & Threonine & ++ & + & + \\
\hline & Valine & ++ & + & ++ \\
\hline & $\begin{array}{l}\text { beta- } \\
\text { Aminobutyric } \\
\text { acid }\end{array}$ & + & + & + \\
\hline & $\begin{array}{l}\text { 4-Aminobutyric } \\
\text { acid }\end{array}$ & + & - & + \\
\hline & Putrescine & + & + & + \\
\hline \multirow{8}{*}{$\begin{array}{l}\text { Sugars and } \\
\text { sugar alcohols }\end{array}$} & Glucose & +++ & + & ++ \\
\hline & Fructose & +++ & + & ++ \\
\hline & Mannose & + & - & - \\
\hline & Maltose & +++ & + & +++ \\
\hline & Trehalose & +++ & + & +++ \\
\hline & Sucrose & +++ & ++ & ++ \\
\hline & Glycerol & +++ & +++ & +++ \\
\hline & Inositol & +++ & + & + \\
\hline \multirow[t]{5}{*}{ Organic acids } & Malate & + & + & + \\
\hline & Fumarate & + & + & + \\
\hline & Succinate & ++ & +++ & ++ \\
\hline & Lauric acid & ++ & + & + \\
\hline & Benzoic acid & ++ & ++ & ++ \\
\hline \multirow[t]{3}{*}{ Others } & Urea & +++ & ++ & ++ \\
\hline & Phosphate & + & + & + \\
\hline & Ornithine & + & + & + \\
\hline
\end{tabular}

$(-$, absent; + , low $;++$, medium; +++ , high $)$.

the onset of the experiment. Also micronutrient concentrations (Table 5) were above the critical levels reported for lettuce by Bergmann (1988). No toxicities, apparent symptoms of diseases or $\mathrm{pH}$ extremes were observed and the soil $\mathrm{pH}$ ranged between 6.6 and 7.6. The soil moisture level was adjusted gravimetrically in regular intervals between $18-20 \%(\mathrm{w} / \mathrm{w})$, equivalent to $70 \%$ of the water holding capacity, which is considered as optimal for plant growth.

\section{DISCUSSION}

Higher plants exhibit an enormous adaptive plasticity of root growth and morphology in response to external biotic and abiotic

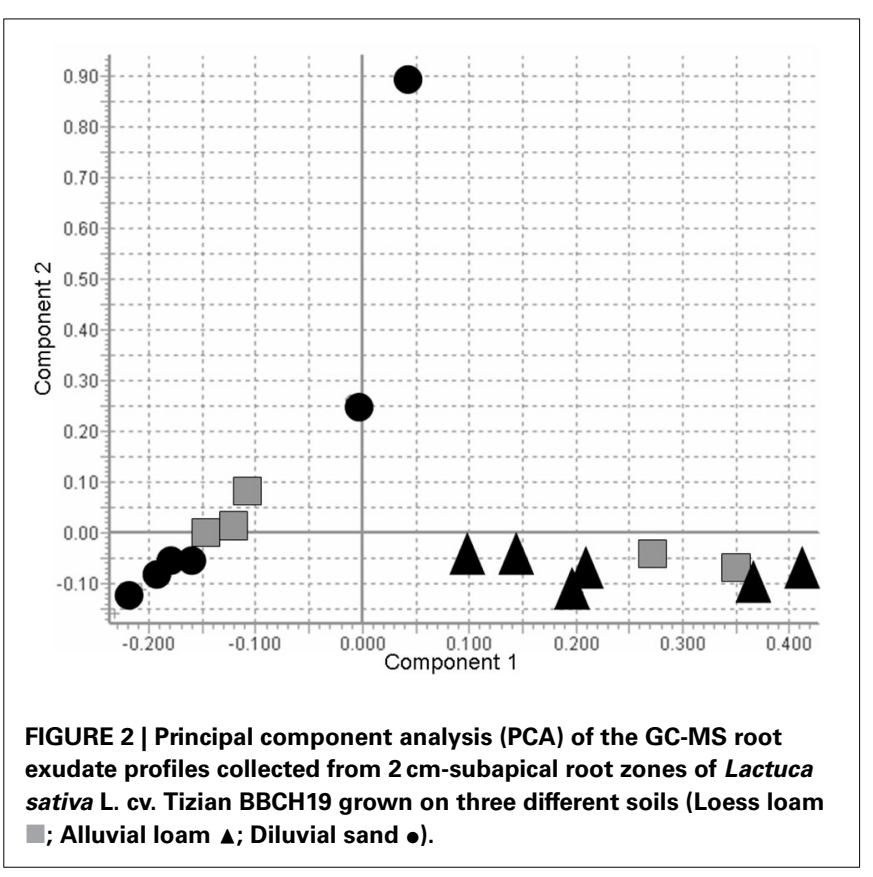

Table 4 | Amounts of sugars, amino acids, and aliphatic organic acids in root exudate samples collected from $2-\mathrm{cm}$ sub-apical root zones of lettuce, Lactuca sativa L. cv. Tizian (BBCH 19) grown on three different soils (calculations based on cumulative peak area after subtraction of background levels in bulk soil samples).

\begin{tabular}{lcrr}
\hline Class of compounds & Alluvial loam & Diluvial sand & Loess loam \\
\hline Sugars & 2.95 & 103.60 & 427.60 \\
Amino acids & 1.39 & 6.05 & 22.66 \\
Organic acids & 2.83 & 0.05 & 4.44 \\
\hline
\end{tabular}

Table 5 | Micronutrient concentrations in leaf dry matter (DM) of young lettuce Lactuca sativa L. cv Tizian (BBCH 19), grown on three different soils.

\begin{tabular}{|c|c|c|c|}
\hline Soil type & $\begin{array}{c}\mathrm{Fe} \\
{\left[\mathrm{mg} \mathrm{kg}^{-1} \mathrm{DM}\right]}\end{array}$ & $\begin{array}{c}\mathrm{Mn} \\
{\left[\mathrm{mg} \mathrm{kg}^{-1} \mathrm{DM}\right]}\end{array}$ & $\begin{array}{c}\mathrm{Zn} \\
{\left[\mathrm{mg} \mathrm{kg}^{-1} \mathrm{DM}\right]}\end{array}$ \\
\hline Loess loam (LL) & $180.2(8.6)$ & $97.1(4.2)$ & $47.8(0.6)$ \\
\hline Diluvial sand (DS) & 308.5 (8.5) & $81.9(16.2)$ & $42.8(2.1)$ \\
\hline Alluvial loam (AL) & $74.3(5.3)$ & $35.0(3.2)$ & $34.5(4.2)$ \\
\hline
\end{tabular}

Means and SES (in brackets) of four independent replicates.

stress factors. Root growth stimulation particularly of fine root structures is frequently induced by moderate limitations of $\mathrm{P}, \mathrm{N}$, $\mathrm{Fe}$, and water but lateral root development and root hair proliferation can be also stimulated by localized patches of high $\mathrm{P}, \mathrm{NO}_{3}^{-}$, and $\mathrm{NH}_{4}^{+}$supply. By contrast, root growth inhibition is a typical response to extreme limitations of water and nutrients, toxicities, and increased mechanical impedance induced by extreme drought or soil compaction (Neumann and Römheld, 2002).

However, in the present study, high variability observed in root growth of lettuce on three different field soils cannot be 
attributed to macronutrient disorders since all soils received a full $\mathrm{N}, \mathrm{P}, \mathrm{K}$, and $\mathrm{Mg}$ fertilization prior to the onset of the experiment. Mineral nutrient analysis revealed soil-specific differences in the plant nutritional status but no apparent nutrient deficiencies or toxicities. Cropping history of the soils during the last 10 years was identical and no symptoms of plant diseases were visible. The largest differences in root length development were detected between the two similarly structured loamy soils (AL and LL), suggesting that also potential effects of soil structure on root growth are not the major cause for the observed variability in root growth. Moreover, the influence of soil structure was further minimized by homogenous sieving of all soils with $2 \mathrm{~mm}$ mesh size prior to the experiment. Therefore, the huge differences observed in root growth and morphology on the three investigated soils were unexpected.

Interestingly, Schreiter et al. (this issue) reported the highest number of bacterial rhizosphere responders in the rhizophere of lettuce grown on AL followed by DS and finally LL soils, which exactly reflects the order of root length development in the different soils (Table 2). Root growth stimulation of host plants by bacterial production of phytohormones (e.g. auxins) is a well-documented mechanism for plant-growth promotion by rhizosphere bacteria (Berg, 2009) and various bacterial genera, such as Rhizobium and Pseudomonas with known potential for root growth stimulation by auxin production (Biswas et al., 2000; Iqbal and Hasnain, 2013) were among the rhizosphere responders detected with the highest abundance in AL soil (Schreiter et al., this issue). This raises the question whether the observed differences in root growth and fine root production of lettuce on the different soils may be the result of differences in the abundance of root growth-promoting rhizobacteria. More fine-root development, resulting in a larger root surface area would in turn also provide increased space for root colonisation by rhizosphere responders.

\section{ROOT EXUDATES}

Apart from variability in root development, also huge quantitative differences particularly for sugars and amino acids were detected in the root exudate samples collected from lettuce plants, grown on the three different soils (Table 5). Comparable variations in root exudation over 1-3 orders of magnitude are characteristic in some plant species for the adaptive release of specific compounds, such as carboxylates or phytosiderophores involved in the mobilization of sparingly soluble mineral nutrients but also for detoxification of toxic elements or in response to membrane damage due to severe nutrient limitations or drought stress (Neumann and Römheld, 2007). However, the presence of nutrient deficiencies/toxicities or of other stress factors, limiting water and nutrient uptake was not indicated by soil and plant analysis (Tables 1, 5) and cannot explain the huge quantitative differences in root exudation. The fact that the samples collected from different soils exhibit mainly quantitative differences, while the qualitative composition was very similar (Table 3) suggests, that the detected compounds represent mainly root exudates and not microbial metabolites. In the latter case, a much higher qualitative diversity would have been expected due to the large variation of microbial populations in the different soils (Schreiter et al., this issue) which would consequently be reflected in a high diversity of microbial metabolites released into the rhizosphere.

However, root exudate sampling was performed over a time period of $4 \mathrm{~h}$ to increase the chance of collecting also less polar aromatic compounds and other secondary metabolites, usually less abundant in root exudates (Neumann, 2006b). On the other hand, longer sampling periods are associated with a risk of losses of readily soluble exudate compounds, such as sugars, amino acids, and organic acids, which are easily used as carbon and N sources by rhizosphere microorganisms (Neumann, 2006b), resulting in half life times of only several hours in rhizosphere soil solutions (Jones et al., 1996). Drastically reduced levels of sugars and amino acids in exudate samples collected from AL as compared with DS and LL soils, may therefore reflect a particularly intense microbial consumption of these compounds as a consequence of a higher abundance of bacterial rhizosphere responders detected by Schreiter et al. (this issue) in the rhizosphere of ALgrown plants. Differences in the root exudate profiles collected from lettuce plants grown on the different soils were further confirmed by PCA (Figure 2).

Another interesting finding is the detection of benzoic and lauric acids in the root exudate samples. Both compounds have been previously reported as constituents of root exudates of lettuce in hydroponic culture with (auto-)allelopathic (Lee et al., 2006) and antifungal properties (Walters et al., 2003; Yoon et al., 2012). Moreover, the rhizosphere responders (Sphingomonas, Pseudomonas, and Variovora) detected by Schreiter et al. (this issue) in the rhizosphere of lettuce grown on the same soils exhibit a high potential for degradation of aromatic hydrocarbons, such as benzoic acid and De la Fuente et al. (2009) reported the ability of various Pseudomonas strains to utilize trehalose and benzoic acids as sole carbon sources, both detected in the root exudates of lettuce in this study.

Urea detected at similar levels, both in bulk soil and root exudate samples (data not shown) cannot be attributed to $\mathrm{N}$ fertilization since nitrate was applied as a mineral $\mathrm{N}$ source. The presence of urea in all analyzed samples may reflect a background level of microbial urea production, which has been previously confirmed by isotope studies also for other agricultural soils (Nielsen et al., 1998). By contrast, phosphate, detected only in root exudate samples may indicate preferential mobilization of weakly adsorbed phosphate in the rhizosphere, mediated by plant roots or rhizosphere microorganisms (Neumann and Römheld, 2002).

In summary, the present study suggests that even under controlled conditions on well-fertilized soils, excluding the influence of cropping history and stress factors with impact on root growth and activity, mutual interactions between plant roots, and soilspecific microbiomes seem to be important determinants for shaping root architecture, root exudation and thereby the establishment of rhizosphere-microbial communities.

\section{REFERENCES}

Badri, D. V., and Vivanco, J. M. (2009). Regulation and function of root exudates. Plant Cell Environ. 32, 666-681. doi: 10.1111/j.1365-3040.2008.01926.x

Bakker, M. G., Manter, D. K., Sheflin, A. M., Weir, T. L., and Vivanco, J. M. (2012). Harnessing the rhizosphere microbiome through plant breeding and agricultural management. Plant Soil 360, 1-13. doi: 10.1007/s11104-012-1361-x 
Berg, G. (2009). Plant-microbe interactions promoting plant growth and health: perspectives for controlled use of microorganisms in agriculture. Appl. Microbiol. Biotechnol. 84, 11-18. doi: 10.1007/s00253-009-2092-7

Bergmann, W. (1988). Ernährungsstörungen bei Kulturpflanzen. 2. Auflage Jena: VEB Gustav Fischer Verlag.

Biswas, J. C., Ladha, J. K., and Dazzo, F. B. (2000). Rhizobia inoculation improves nutrient uptake and growth of lowland rice. Soil Sci. Soc. Am. J. 64, 1644-1650. doi: 10.2136/sssaj2000.6451644x

Chaparro, J. M., Badri1, D. V., Bakker, M. G., Sugiyama, A., Manter, D. K., and Vivanco, J. M. (2013). Root exudation of phytochemicals in Arabidopsis follows specific patterns that are developmentally programmed and correlate with soil microbial functions. PLoS ONE 8:e55731. doi: 10.1371/journal.pone.0055731

De la Fuente, L., Mavrodi, D. L., Thomashow, L. S., and Weller, D. M. (2009). Utilization of trehalose, benzoate, valerate, and seed and root exudates by genotypes of 2,4-diacetylphloroglucinol producing Pseudomonas fluorescens. Soil Biol. Biochem. 39, 2712-2722. doi: 10.1016/j.soilbio.2007.04.029

Haase, S., Neumann, G., Kania, A., Kuzyakov, Y., Römheld, V., and Kandeler, E. (2007). Atmospheric $\mathrm{CO}_{2}$ and the $\mathrm{N}$-nutritional status modifies nodulation, nodule-carbon supply and root exudation of Phaseolus vulgaris L. Soil Biol. Biochem. 39, 2208-2221. doi: 10.1016/j.soilbio.2007.03.014

Hiltner, L. (1904). Über neuere Erfahrungen und Probleme auf dem Gebiete der Bodenbakteriologie unter besonderer Berücksichtigung der Gründüngung und Brache. Arb. DLG 98, 59-78.

Iqbal, A., and Hasnain, S. (2013). Auxin producing Pseudomonas strains: biological candidates to modulate the growth of Triticum aestivum beneficially. Am. J. Plant Sci. 4, 1693-1700. doi: 10.4236/ajps.2013.49206

Jones, D. L., Prabowo, A. M., and Kochian, L. (1996). Kinetics of malate transport and decomposition in acid soils and isolated bacterial populations: the effect of microorganisms on root exudation of malate under Al stress. Plant Soil 181, 239-247. doi: 10.1007/BF00029055

Lee, J. G., Lee, B. Y., and Lee, H. J. (2006). Accumulation of phytotoxic organic acids in reused nutrient solution during hydroponic cultivation of lettuce (Lactuca sativa L.). Sci. Hortic. 110, 119-128. doi: 10.1016/j.scienta.2006.06.013

Lippmann, R., Kaspar, S., Rutten, T., Melzer, M., Kumlehn, J., Matros, A., et al. (2009). Protein and metabolite analysis reveals permanent induction of stress defense and cell regeneration processes in a tobacco cell suspension culture. Int. J. Mol. Sci. 10, 3012-3032. doi: 10.3390/ijms10073012

Marschner, H. (1995). Mineral Nutrition of Higher Plants. 2nd Edn. London: Academic Press.

Marschner, P., Neumann, G., Kania, A., Weiskopf, L., and Lieberei, R. (2002). Spatial and temporal dynamics of the microbial community structure in the rhizosphere of cluster roots of white lupin (Lupinus albus L.). Plant Soil 246, 167-174. doi: 10.1023/A:1020663909890

Neumann, G. (2006a). "Culture systems," in Handbook of Methods used in Rhizosphere Research, eds J. Luster, R. Finlay, I. Brunner, W. J. Fitz, B. Frey, A. Göttlein, et al. (Birmensdorf: Swiss Federal Institute for Forest, Snow, and Landscape Research), 143-144.

Neumann, G. (2006b). "Root exudates and organic composition of plant roots," in Handbook of Methods used in Rhizosphere Research, eds J. Luster, R. Finlay,
I. Brunner, W. J. Fitz, B. Frey, A. Göttlein, et al. (Birmensdorf: Swiss Federal Institute for Forest, Snow, and Landscape Research), 317-318.

Neumann, G. (2007). "Root exudates and nutrient cycling," in Nutrient cycling in Ecosystems, Soil Biology, Vol. 10, eds P. Marschner and Z. Rengel (Berlin; Heidelberg: Springer), 123-157.

Neumann, G., George, T. S., and Plassard, C. (2009). Strategies and methods for studying the rhizosphere - the plant science toolbox. Plant Soil 321, 431-456. doi: 10.1007/s11104-009-9953-9

Neumann, G., and Römheld, V. (2002). "Root-induced changes in the availability of nutrients in the rhizosphere," in Plant Roots The Hidden Half, 3rd Edn., eds Y. Waisel, A. Eshel, and U. Kafkafi (New York, NY: Marcel Dekker), 617-649.

Neumann, G., and Römheld, V. (2007). "The release of root exudates as affected by the plant physiological status," in The Rhizosphere: Biochemistry and Organic Substances at the Soil-Plant Interface, 2nd Edn., eds R. Pinton, Z. Varanini, and P. Nannipieri (Boca Raton, FL: CRC Press), 23-72.

Nielsen, T. H., Bonde, T. A., and Sörensen, J. (1998). Significance of microbial urea turnover in N cycling of three Danish agricultural soils. FEMS Microbiol. Ecol. 25, 147-157. doi: 10.1111/j.1574-6941.1998.tb00468.x

Walters, D. R., Walker, L. R., and Walker, K. C. (2003). Lauric acid exhibits antifungal activity against plant pathogenic fungi. J. Phytopathol. 151, 228-230. doi: 10.1046/j.1439-0434.2003.00713.x

Weisskopf, L., Abou-Mansour, E., Fromin, N., Tomasi, N., Santelia, D., Edelkott, I., et al. (2006). White Lupin has developed a complex strategy to limit microbial degradation of secreted citrate required for phosphate nutrition. Plant Cell Environ. 29, 919-927. doi: 10.1111/j.1365-3040.2005.01473.x

Yoon, M. Y., Seo, K. H., Lee, S. H., Choi, G. J., Jang, K. S., Choi, Y. H., et al. (2012). Antifungal activity of benzoic acid from Bacillus subtilis GDYA-1 against fungal phytopathogens. Res. Plant Dis. 18, 109-114. doi: 10.5423/RPD.2012. 18.2.109

Conflict of Interest Statement: The authors declare that the research was conducted in the absence of any commercial or financial relationships that could be construed as a potential conflict of interest.

Received: 08 November 2013; accepted: 03 January 2014; published online: 24 January 2014.

Citation: Neumann G, Bott S, Ohler MA, Mock H-P, Lippmann R, Grosch R and Smalla K (2014) Root exudation and root development of lettuce (Lactuca sativa L. cv. Tizian) as affected by different soils. Front. Microbiol. 5:2. doi: 10.3389/fmicb. 2014.00002

This article was submitted to Plant-Microbe Interaction, a section of the journal Frontiers in Microbiology.

Copyright (c) 2014 Neumann, Bott, Ohler, Mock, Lippmann, Grosch and Smalla. This is an open-access article distributed under the terms of the Creative Commons Attribution License (CC BY). The use, distribution or reproduction in other forums is permitted, provided the original author(s) or licensor are credited and that the original publication in this journal is cited, in accordance with accepted academic practice. No use, distribution or reproduction is permitted which does not comply with these terms. 